\title{
Diversity of endophytic fungi in Syzygium aqueum
}

\author{
UMMI H. HABISUKAN ${ }^{1,2,}$, ELFITA $^{3, v \vee}$, HARY WIDJAJANTI ${ }^{4}$, ARUM SETIAWAN ${ }^{4}$, \\ ALFIA R. KURNIAWATI ${ }^{2}$ \\ ${ }^{1}$ Graduate School of Sciences, Faculty of Mathematics and Natural Sciences, Universitas Sriwijaya. Jl. Padang Selasa No. 524, Palembang 30139, South \\ Sumatra, Indonesia. `email: ummihirash@gmail.com \\ ${ }^{2}$ Department of Biology Education, Faculty of Tarbiyah and Teacher Training, Universitas Islam Negeri Raden Fatah. Jl. Prof. K.H. Zainal Fikri, \\ Palembang 30126, South Sumatra, Indonesia \\ ${ }^{3}$ Department of Chemistry, Faculty of Mathematics and Natural Sciences, Universitas Sriwijaya. Jl. Raya Palembang-Prabumulih Km 32, Indralaya, \\ Ogan Ilir 30662, South Sumatra, Indonesia. Tel.: +62-711-580056, "email: elfita69@ gmail.com \\ ${ }^{4}$ Department of Biology, Faculty of Mathematics and Natural Sciences, Universitas Sriwijaya. Jl. Raya Palembang-Prabumulih Km 32, Indralaya, Ogan
} Ilir 30662, South Sumatra, Indonesia

Manuscript received: 15 October 2020. Revision accepted: 2 February 2021.

\begin{abstract}
Habisukan UH, Elfita, Widjajanti H, Setiawan A, Kurniawati AR. 2021. Diversity of endophytic fungi in Syzygium aqueum. Biodiversitas 22: 1129-1137. Exploring endophytic fungi may provide alternative, plant-based ethnomedicines. The discovery of endophytic fungi can produce many plant-derived drugs that give new horizons to the pharmaceutical industry for the availability and production of such medicines on a large scale. Extracts from Syzygium aqueum Alston (jambu air), a fruit-bearing plant native to Indonesia, have long been used in traditional medicine. Therefore, the purpose of this study was to identify, and investigate, the antimicrobial activity of the endophytic fungi found in $S$. aqueum. Results revealed that total16 fungi were isolated from different tissues (stem bark, root bark, and leaves) of the plant. Fungal endophytes were identified through morphological characterization and subsequently compared with key fungal identification books. The ethyl acetate extracts of the isolated endophytic fungi were screened for their antimicrobial activity through paper disc diffusion assay fungi isolated from S. aqueum were identified as: Aspergillus niger (Isolate code R21, R41, T72), Cylindrocarpon sp. (Isolate code R11, R31), Trichoderma aureoviridae (Isolate code T11), Trichoderma harzianum (Isolate code T21), Trichoderma sp. (Isolate code T31), Pestalotia sp. (Isolate code T41and T62), Beltrania sp. (Isolate code T52), Chaetomium sp. (Isolate code L11), Cochliobolus sp. (Isolate code L22), Penicillium sp. (Isolate code L32), Cylindrocladium sp. (Isolate code L42), and an unidentified Ascomycota (T51). The values of Shannon-Weiner and Simpson diversity indexes for the overall fungal community were $\mathrm{H}^{\prime}=2.133$ and $1-\mathrm{D}=0.859$ respectively. All isolates showed potential antimicrobial activity against Escherichia coli, Salmonella Typhi, and Staphylococcus aureus, but the lowest activity against Candida albicans. The results indicate that the bioactive compounds and secondary metabolites of these isolates should be further investigated for pharmaceutical applications.
\end{abstract}

Keywords: Antimicrobial activity, diversity, endophytic fungi, fungal identification, Syzygium aqueum

\section{INTRODUCTION}

Syzygium aqueum Alston, which belongs to the Myrtaceae family, is a fruit-bearing plant native to Indonesia and Malaysia. In Indonesia, it is well known as jambu air. The leaves, bark, roots, and other tissues of $S$. aqueum have long been used in traditional medicine (Cock and Cheesman 2018). It has antibiotic, anti-inflammatory, antioxidant, and anti-tyrosinase properties (Palanisamy et al. 2011; Cock and Chessman 2018). Of these properties, the current researchers have chosen to analyze the antimicrobial activity of $S$. aqueum, which has also been highlighted by Mapatac and Mapaoag (2014) and Chua et al. (2019). Microbial infections are serious challenges to human health because of microbial resistance to antibiotics (Dos Santoz et al. 2015). Plant-based ethnomedicines are derived from compounds occurring in plant extracts. Investigating the properties of endophytic fungi could be an alternative prospect for producing plant-derived compounds, which will benefit the pharmaceutical industry (Nicoletti and Florentino 2015).

Endophytic fungi are polyphyletic microorganisms, which inhabit plant tissues without inciting disease symptoms and eventually establish mutualistic associations with their host plants. Numerous studies have been conducted on the diversity and isolation of endophytic fungi, which have revealed that fungi in plants are important and quantitative components of biodiversity, which have an impact on the diversity and composition of the plant community (Porras-Alfaro and Bayman 2011; Potshangbam et al. 2017). Exploration of the biosynthetic potential of endophytes has gained attention due to the ongoing discovery of strains that can synthesize plant compounds - a property that may reflect the adaptive functional role of endophytes in biocenosis (Nicoletti and Florentino 2015). Secondary metabolites serve multiple physiological functions, and, in a way, it is intuitive that similar compounds may be produced by ecologically associated entities (Jumpathong et al. 2010; Elfita et al. 2013; Budiono et al. 2019). Medicinal plants usually contain endophytic fungi, which produce natural compounds, similar to those found in the host plant such as saponins, alkaloids, flavonoids, tannins, phenolics, glycosides, and terpenoids (Budiono et al. 2019; Madhavi Ram 2015). 
This is an initial step in exploring the potential of endophytic fungi as alternative strategies for the production of natural antimicrobial agents, and since there is no literature available for fungal communities associated with $S$. aqueum, the objectives of this study were: (i) to identify the endophytic fungi present in $S$. aqueum, (ii) to investigate the diversity of fungi associated with the stem bark, root bark, and leaves of $S$. aqueum, and (iii) to examine the antimicrobial activity of endophytic fungal extract.

\section{MATERIALS AND METHODS}

\section{Sample collection}

Syzygium aqueum plant samples were obtained from Ogan Ilir Regency, South Sumatra, Indonesia. Plant identification was confirmed at the Biosystematics Laboratory, Biology Department, Sriwijaya University, Ogan Ilir, Indonesia with certificate no. 329//UN9.1.7/4/EP/2020. Fresh and healthy samples of $S$. aqueum stem bark, root bark, and leaves were immediately transported to the laboratory.

\section{Isolation of endophytic fungi}

The $S$. aqueum stem bark, root bark, and leaf samples were washed with running tap water for $10 \mathrm{~min}$ and then air-dried. Sample fragments were successively surface sterilized by immersing each sample in $70 \%$ alcohol for $\pm 1 \mathrm{~min}$, followed by immersion in $3 \%(\mathrm{w} / \mathrm{v})$ sodium hypochlorite $(\mathrm{NaOCl})$ for $1 \mathrm{~min}$. After being rinsed in sterile distilled water for $\pm 1 \mathrm{~min}$, the outer tissue of sample was removed with a sterile scalpel. Small pieces of stem bark, root bark, and leaves were placed in Petri dishes containing potato dextrose agar (PDA) media (200 g potato, $20 \mathrm{~g}$ dextrose, and $15 \mathrm{~g}$ agar in $1 \mathrm{~L}$ of $\mathrm{H}_{2} \mathrm{O}$ ) supplemented with chloramphenicol $(0.2 \mathrm{~g} / \mathrm{L})$. Petri dishes were then incubated at $30 \pm 2^{\circ} \mathrm{C}$ for seven days in the dark. All experiments were performed in triplicates. For the fungal growth from the leaf segments, the plates were monitored every day. Individual hyphal tips were transferred into fresh PDA and incubated at $30^{\circ} \mathrm{C}$ for seven days. The pure cultures were numbered, maintained in PDA slants, and kept at $4^{\circ} \mathrm{C}$ (Muharni et al. 2014; Elfita et al. 2019).

\section{Identification of endophytic fungi}

Macroscopic and microscopic features were used to characterize the morphology of the endophytic fungal isolates. Macroscopic characterization was based on the colony growth pattern, texture, margins, color, and other features. The microscopic characterization employed the slide culture method. Endophytic fungal cultures were placed on slides and mixed with one drop of lactophenol blue reagent. These slides were examined under a light microscope. The morphological characteristics data were then compared with key fungi identification books (Barnett 1969; Gandjar 1999; Watanabe 2002; Pitt and Hocking 2009).

\section{Fungal diversity and ecological associations}

Fungal diversity was estimated for each tissue sample and for the total sample population using the ShannonWeiner (Shannon and Weiner 1949) and the Simpson (Simpson 1949) diversity indexes. Principal Component Analysis (PCA) was used to study the ecological interrelationships between the fungal species and different plant tissue types (PAST software, Hammer et al. 2001).

\section{Cultivation and extraction}

For the cultivation inoculum of fungi $\left( \pm 10^{6}\right.$ spores $\left./ \mathrm{mL}\right)$ was inoculated as much as $5 \%(\mathrm{v} / \mathrm{v})$ in $300 \mathrm{ml}$ of a potato dextrose broth (PDB) medium (20g dextrose monohydrate, $200 \mathrm{~g}$ potato, and $1,000 \mathrm{~mL}$ aquadest) in $1 \mathrm{~L}$ bottles. They were then incubated at room temperature for four to eight weeks. Color change in the samples indicated that secondary metabolite compounds had been formed. As a comparison, $300 \mathrm{ml}$ of the PDB medium was placed into a separate $1 \mathrm{~L}$ bottle along with secondary metabolites, which had been partitioned in ethyl acetate and extracted via evaporation (Elfita et al. 2019; Gustianingtyas et al. 2020). The concentrated extracts were used for antimicrobial assay.

\section{Antimicrobial activity}

Antimicrobial activity was carried out via paper disc diffusion assay. Each sample was dissolved in dimethyl sulfoxide $10 \%$ (DMSO; Merck, Germany), and the antibacterial activity was evaluated against one grampositive bacterium ( $S$. aureus), two gram-negative bacteria (S. typhi and E. coli), and one yeast (C. albicans). These organisms were maintained on Muller-Hinton agar (MHA). The resulting suspension turbidity was diluted with sterile aquadest to match a $0.5 \mathrm{McFarland}$ turbidity standard (1 MacFarland is equivalent to approximately $3.0 \mathrm{x}$ $10^{8} \mathrm{CFU} / \mathrm{mL}$ ) (Singh et al. 2015). The extract concentration used for this assay was $1,000 \mu \mathrm{g} / \mathrm{mL}$. Absorbent disc (Whatman, $6.0 \mathrm{~mm}$ in diameter) was impregnated with $10 \mu \mathrm{L}$ of the solution and then placed on the surface of inoculated plates $(90 \mathrm{~mm})$. Positive control discs of ciprofloxacin $10 \mu \mathrm{L} / \mathrm{mL}$ were excluded from the assay. Diameters of the growth inhibition zones were measured after incubation at $37^{\circ} \mathrm{C}$ for $24 \mathrm{~h}$. All experiments were performed in triplicates (Talukdar et al. 2020).

\section{RESULTS AND DISCUSSION}

A total of 16 endophytic fungi were isolated from different tissues (stem bark, root bark, and leaves) of $S$. aqueum. The growth of endophytic fungi isolates was indicated by the appearance of hyphae around the plant tissue segments (Figure 1). The colonies of fungal isolates exhibited various physical appearances. Massive hyphae growth appeared in the stem bark samples, with white colony dominance and yellow pigmentation. White filament colonization appeared around the root bark segments, and small, dark green and white colonies appeared on the leaf segments. 


\section{Identification of endophytic fungi}

The 16 fungal colonies exhibited diversity in colors (white, black, green, and yellow) and texture (velvety, powdery, cottony, and granularly). Only isolates T11 and T21 evidenced exudates droplets and emitted yellow pigment. The macroscopic features of the isolated fungi are presented in Table 1.

Microscopic analysis showed that 16 isolates belong to ten different genera. Nine identified genera were (Aspergillus, Cylindrocarpon, Trichoderma, Pestalotia, Beltrania, Chaetomium, Penicillium, Cochliobolus, and Cylindrocladium) and one unidentified genus from the Ascomycota phylum
(Table 2). The endophytic fungi isolated from $S$. aqueum showed diversity in their spore shapes (cylindrical, globose, subglobose, spindle, and ellipsoidal). Most of the isolates had septate hyphae, except for isolates R11, R31, T51, and L11, which had coenocytic hyphae.

Four endophytic fungi were isolated from the root bark of $S$. aqueum (Figure 2), with the codes R11, R21, R31, and R41. Isolates R21 and R41 were spreading black colonies with white margins (Figure 2), and the microscopic characteristics showed that they had hyaline straight conidiophores, round vesicles, fialid circling vesicles, and round, black conidia.

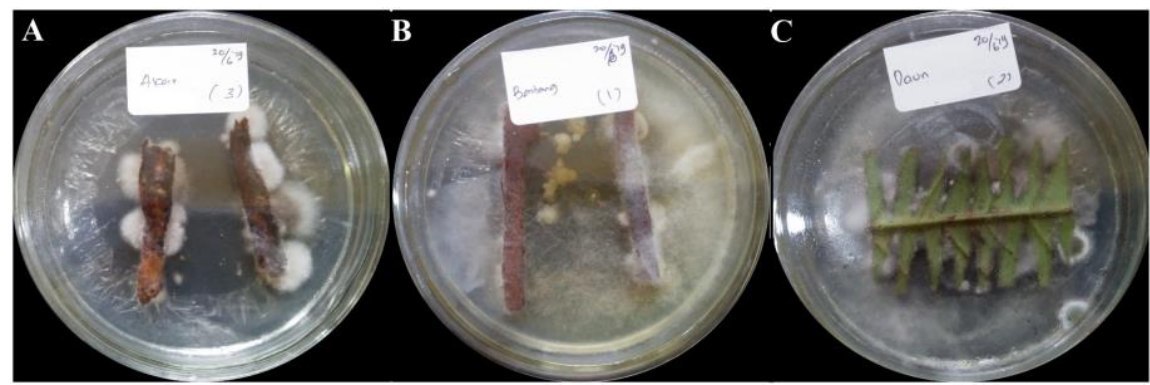

Figure 1. Mycelium appearance of endophytic fungi around Syzygium aqueum segments; A. Root bark; B. Stem bark; C. Leaves

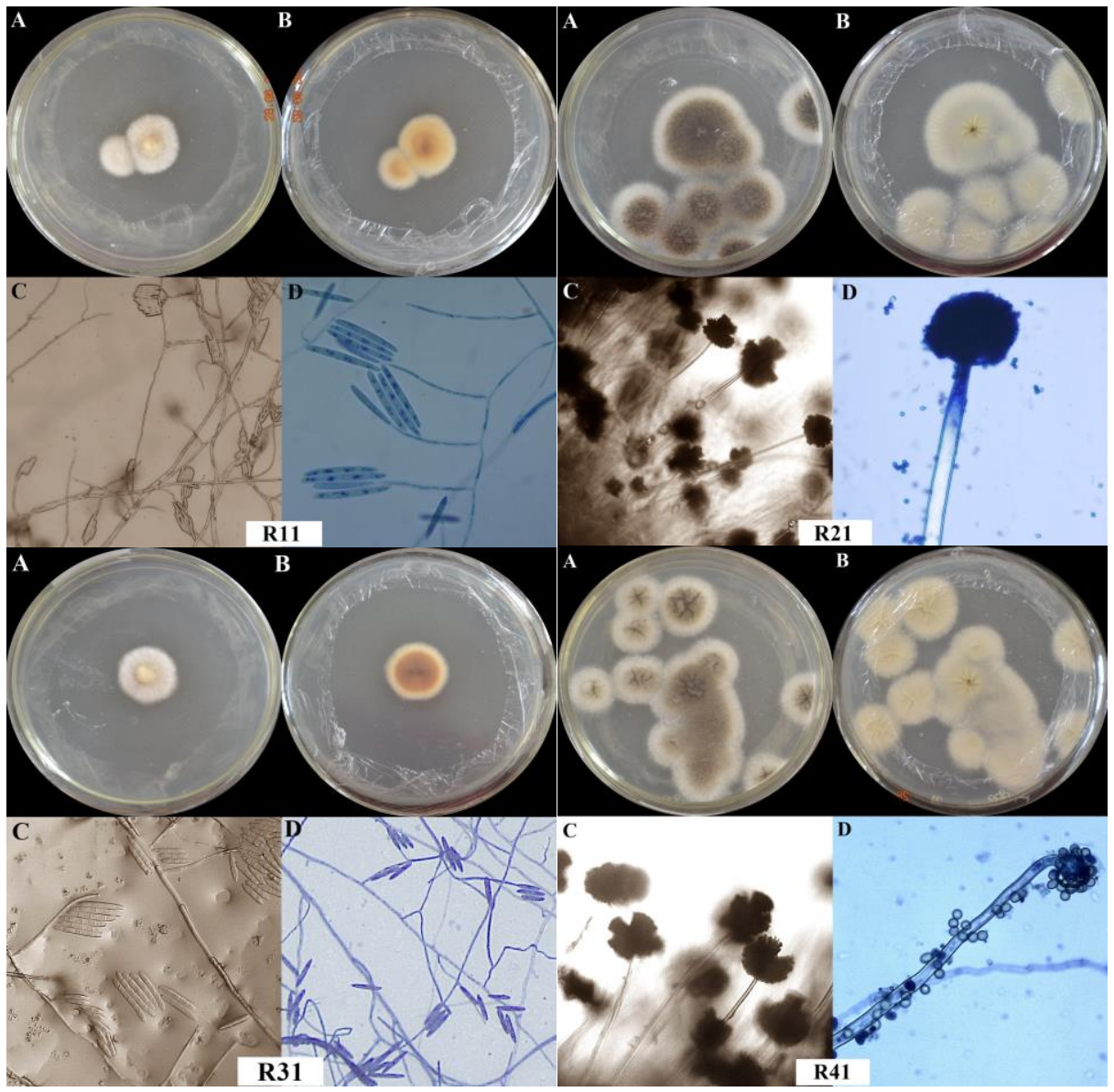

Figure 2. Morphology of endophytic fungi isolated from Syzygium aqueum root bark. R11. Cylindrocarpon sp., R21. A. niger, R31. Cylindrocarpon sp., R41. A. niger; A. Front view colony; B. Reverse colony; C. Conidia without staining; D. Conidia with lactophenol blue dye 
According to the key identification books, these isolates were identified as A. niger, which has specific features including black mass spores with globose vesicles. Isolate T72 had similar morphological characteristics to isolates $\mathrm{R} 21$ and R41, therefore isolate T72 was also identified as A. niger.

Isolates R11 and R31 were yellowish-white colonies with umbonate topography. Their microscopic features showed simple conidiospores (phialides). They were hyaline, erect, perceptic, and mostly 4-5-septate. They also evidenced ellipsoidal conidia and were apiculate at one end, slightly straight on one side, and curved on one side. According to their morphology, the closest species resembling R11 and R31 was Cylindrocarpon sp.

Isolate T41 was a white flowery colony with a cottony surface (Figure 3, T41 a-b). Microscopically, it showed short conidiospores, in spindle or ellipsoidal shapes, with four to five cells, two to three centrally pigmented cells, two to four appendages (setulae) in the apical cells, and one short appendage (pedicel) at the basal cell. Based on these characteristics, isolate T41 was identified as Pestalotia sp.
Isolate T52 (Figure 3, T52 a-b) was showing greenish brown with white margins and grew in a flowery pattern. Isolate T52 had pale brown conidiophores, had simple and occasionally proliferated forming nodes, and was inflated slightly at the apex. Beltrania sp. was the closest match to the fungus.

Four endophytic isolates i.e. L11, L22, L32, and L42 were isolated from the leaves of $S$. aqueum (Figure 4). Isolate L11 showed round, white colony with a cottony surface. Microscopically, it had dark perithecia and subglobose or ovate spores. It was covered with terminal hairs on the upper surface and was rhizoidal at its base. Thus, isolate L11 was thought to be closest to Chaetomium sp. Isolate L22 had a white cottony surface with a dark reverse color. Microscopically, it had septate hyphae, and its conidiophores were upright, brown, branched, straight or curved, porous, and subellipsoidal. It was mostly fourcell and was darker brown at the two-cell center, with a larger middle at the peripheral cells and indistinct hilar at the base. Thus, the characteristics of isolate L22 were considered to be closest to those of Cochliobolus sp.

Table 1. Macroscopic characteristics of endophytic fungi isolated from Syzygium aqueum

\begin{tabular}{|c|c|c|c|c|c|c|c|c|}
\hline Isolate & Colony color & $\begin{array}{c}\text { Reverse colony } \\
\text { color }\end{array}$ & Texture & Topography & Pattern & $\begin{array}{c}\text { Exudate } \\
\text { drops }\end{array}$ & $\begin{array}{l}\text { Radial } \\
\text { line }\end{array}$ & $\begin{array}{c}\text { Concentric } \\
\text { circle }\end{array}$ \\
\hline R11 & Yellowish white & Dark brown & Velvety & Umbonate & Zonate & - & $\sqrt{ }$ & - \\
\hline $\mathrm{R} 21$ & Black & Broken white & Powdery & Rugose & Spread & - & - & - \\
\hline R31 & Yellowish white & Dark brown & Velvety & Umbonate & Zonate & - & $\sqrt{ }$ & - \\
\hline R41 & Black & Broken white & Powdery & Rugose & Spread & - & - & - \\
\hline $\mathrm{T} 11$ & White with green spots & Light yellow & Granular & Flat & Radiate & $\sqrt{ }$ & - & $\sqrt{ }$ \\
\hline $\mathrm{T} 21$ & White with green spots & Light yellow & Granular & Flat & Radiate & $\sqrt{ }$ & - & $\sqrt{ }$ \\
\hline T31 & Dark green and white & Greenish white & Cottony & Umbonate & Zonate & - & $\sqrt{ }$ & $\sqrt{ }$ \\
\hline $\mathrm{T} 41$ & White & Yellowish white & Cottony & Flat & Flowery & - & $\sqrt{ }$ & - \\
\hline T51 & Light green and white & Greenish white & Granular & Umbonate & Zonate & - & $\sqrt{ }$ & $\sqrt{ }$ \\
\hline $\mathrm{T} 52$ & Brown and greenish-white & Army green & Cottony & Flat & Flowery & - & $\sqrt{ }$ & $\sqrt{ }$ \\
\hline T62 & Dark green and white & Greenish white & Cottony & Umbonate & Zonate & - & $\sqrt{ }$ & $\sqrt{ }$ \\
\hline $\mathrm{T} 72$ & Black & Broken white & Powdery & Rugose & Spread & - & - & - \\
\hline L11 & White & Yellowish white & Cottony & Convex & Zonate & - & - & - \\
\hline L22 & Grey with marginal white & Black with marginal white & Cottony & Verrucose & Zonate & - & - & $\sqrt{ }$ \\
\hline L32 & Dark green and white & Broken white & Powdery & Rugose & Spread & - & - & - \\
\hline L41 & White & White & Cottony & Verrucose & Flowery & - & $\sqrt{ }$ & - \\
\hline
\end{tabular}

Note: -: characteristic does not appear; $\sqrt{ }$ : characteristic appear

Table 2. Microscopic characteristics and list of endophytic fungi isolated from Syzygium aqueum

\begin{tabular}{|c|c|c|c|c|c|}
\hline Isolate & Type of spore & Shape of spore & Hyphae & Specific characteristic & Genus / species \\
\hline $\bar{R} 11$ & Conidia & Cylindrical & Coenocytic & Macroconidia cylindrical, 4-5 septate & Cylindrocarpon $\mathrm{sp}$. \\
\hline $\mathrm{R} 21$ & Conidia & Globose & Septate & Globose vesicle, conidia black in mass & Aspergillus niger \\
\hline R31 & Conidia & Cylindrical & Coenocytic & Macroconidia cylindrical, 4-5 septate & Cylindrocarpon sp. \\
\hline R41 & Conidia & Globose & Septate & Globose vesicle, conidia black in mass & Aspergillus niger \\
\hline $\mathrm{T} 11$ & Conidia & Subglobose & Septate & Phialide verticillate, chlamydospore subglobose & Trichoderma aureoviridae \\
\hline $\mathrm{T} 21$ & Conidia & Subglobose & Septate & Spore masses apically at verticillate phialides & Trichoderma harzianum \\
\hline T31 & Conidia & Globose & Septate & Phialide verticillate, chlamydospore subglobose & Trichoderma sp. \\
\hline T41 & Conidia & Spindle & Septate & Conidia spindle, pigmented cell, apparent appendages & Pestalotia spp. \\
\hline T51 & Sporangia & Glob & Coenocytic & Branched hyphae, apparent asci with granular spore & Uniden \\
\hline $\mathrm{T} 52$ & Conidia & Globc & Septate & dia sympodially & Beltrania sp. \\
\hline T62 & Conidia & Ellipsoidal & Septate & Phialide verticillate, chlamydospore subglobose & Trichoderma sp. \\
\hline $\mathrm{T} 72$ & Conidia & Globose & Septate & Globose vesicle, conidia black in mass & Aspergillus niger \\
\hline $\mathrm{L} 11$ & Ascospore & Subglobose & Coenocytic & Ascocarps with well-developed hair, perithecia black & Chaetomium sp. \\
\hline $\mathrm{L} 22$ & Conidia & Ellipsoidal & Septate & Subellipsoidal, mostly four-celled, central dark brown & Cochliobolus sp. \\
\hline L32 & Conidia & Globose & Septate & Branch apex, 2-3 metulae, verticillate phialides & Penicillium sp. \\
\hline $\mathrm{L} 42$ & Conidia & Cylindrical & Septate & Terminal vesicle subglobose, clavate, lanceolate & Cylindrocladium sp. \\
\hline
\end{tabular}


Macroscopically, isolate L32 (Figure 4) was a spreading, dark green color colony with white edges. The reverse colony was yellowish white. Microscopically (Figure 1E), it had upright hyaline conidiophores, which branched into two to three metulae; each metula contained verticillate phialides, and each phialide contained dangling, round, green conidia. After comparison, isolate L22 was identified as Penicillium sp.

Isolate L42 identified as Cylindrocladium sp. The colony was white with a more yellowish reverse colony. Its surface was cottony, and it grew in a flowery pattern (Figure 4, L42 a-b). Its conidiophores were erect and branched, with elongated primary and secondary branches. The phialide branches carried spore masses with cylindrical stalk and terminal vesicles. The conidia were cylindrical and phialosporous (Figure 4, L42 c-d).

\section{Endophytic fungal diversity and ecological association}

Eight isolates were obtained from the stem bark of $S$. aqueum, and four were obtained from the root bark and leaves. The diversity index values (Shannon-Wiener and Simpson) of S. aqueum tissues are listed in Table 3. The $\alpha$ diversity values were obtained via the PAST software (Shadegi et al. 2019). The Shannon-Weiner and Simpson diversity index values were highest in leaves $\left(\mathrm{H}^{\prime}=1.386\right.$ and $1-\mathrm{D}=0.750$, respectively) and lowest in root bark $\left(\mathrm{H}^{\prime}=0.693\right.$ and $1-\mathrm{D}=0.500$, respectively). In addition, the overall diversity values of the endophytic fungal populations were $\mathrm{H}^{\prime}=2.133$ and $1-\mathrm{D}=0.859$ (Table 3 ).

The two principal components or axes (1-2) obtained via PCA explained $68 \%$ of the total fungal variation (Figure 5). The analysis showed that some isolates had an affinity for a specific tissue. Host affinity could reflect functional differences in phenology, chemistry, or other traits, which vary among fungi and host plant taxa. Differences in diversity and species composition between stems and leaves may also reflect their functional similarities.

\section{Antimicrobial activity of endophytic fungi}

Antimicrobial activity of the endophytic fungi isolated from $S$. aqueum is presented in Table 4. Ten out of 16 isolates were used in the antimicrobial analysis. Overall, the endophytic fungal extracts inhibited the growth of the three bacterial species, but they had little effect on the yeast (C. albicans). Isolate $\mathrm{R} 42$ (A. niger) showed strong antimicrobial activity against $E$. coli, and isolate T31 ( $T$. harzianum) showed strong antimicrobial activity against $S$. aureus and S. typhi. On average, the lowest level of antimicrobial activity was presented by isolate L22 (Cochliobolus sp.).

\section{Discussion}

The sampling of $S$. aqueum endophytes indicated that a diverse community of fungi live on the plant's various tissues. The purpose of surface sterilization during the isolation process was to remove microorganisms from the plant surface so that the fungi growing in the media are only endophytic fungi (Strobel and Daisy 2003). 3\%
$\mathrm{NaOCl}$ and $70 \%$ alcohol were used in chemical solutions for surface sterilization as both are widely employed as disinfectants. Hypochlorite ions regenerated from hypochlorous acid $(\mathrm{HOCl})$ and dissolved in water are capable of damaging bacterial plasma membranes (Rahayu et al. 2019).

Results showed that all endophytic fungi isolated from the different tissues of $S$. aqueum were categorized into three classes of Ascomycota: Eurotiomycetes, Sordariomycetes, and Ascomycetes. To date, most fungi reported as endophytes have been identified as Ascomycetes and their anamorphs. Basidiomycetous endophytes have only been reported in a limited number of studies (Rivera-Orduña et al. 2011; Sridhar and Raviraja 1995; Wang et al. 2005). The most evenly distributed genus was Trichoderma isolated only from S. aqueum stem bark. Trichoderma species are typically soilborne organisms commonly associated with plant roots and stems. Some strains of Trichoderma, such as T. harzianum, $T$. stromaticum, and T. asperellum, have antagonistic effects on some fungal diseases (Bailey et al. 2008; Gazis and Chaverri 2010).

Some isolated endophytic taxa prefer specific tissue types. Some sapwood endophytes may invade tree hosts through their root systems, moving from the soil to their new niche inside the plant (Gazis and Chaverri 2010). In this research, PCA showed an increased occurrence and frequency of tissue specificity (Rodrigues 1994; Photita et al. 2001; Kumar and Hyde 2004). Certain endophytes were found only in one $S$. aqueum tissue (stem bark, root bark, or leaves), indicating that they may have an affinity for a particular tissue type (Rivera-Orduña et al. 2011). The fungal endophytes from $S$. aqueum had a greater affinity for the stem bark than for any other tissue.

Antimicrobial analysis results showed that endophytic fungal extracts have the ability to inhibit the growth of bacterial species. Hariyati et al. (2015) reported that $S$. aqueum leaf extract inhibited the growth of Shigella dysentriae, Vibrio cholerae, S. aureus, E. Coli, and S. typhi. He also reported that $S$. aqueum left extract showed strong activity against E. Coli, $S$ typhi, and $S$. aureus at $50 \%$ concentration. Sobeh et al. (2016) have also reported that some bioactive compounds are found in the essential oils of $S$. aqueum leaves, which exhibit antimicrobial activity. Phenolic and flavonoid compounds are dominant in the $S$. aqueum plant, and both have strong antioxidant and antimicrobial properties (Tehrani et al. 2011; Palanisamy et al. 2011; Marinova 2005). The in vitro antibacterial activity of several classes of polyphenols can be due to direct action against bacteria, viruses, and fungi, as well as the suppression of microbial virulence factors (Daglia 2012). The most common constituents in $S$. aqueum with antimicrobial properties are $\alpha$-selinene, $\beta$ caryophyllene, and $\beta$-selinene (Sobeh et al. 2016). Trichoderma species showed strong antimicrobial activity against S. aureus and S. typhi. Trichoderma species can protect their hosts from direct parasitism, antibiosis, and nutrient competition via enhanced plant growth or induced resistance (Gazis and Chaverri 2010). 


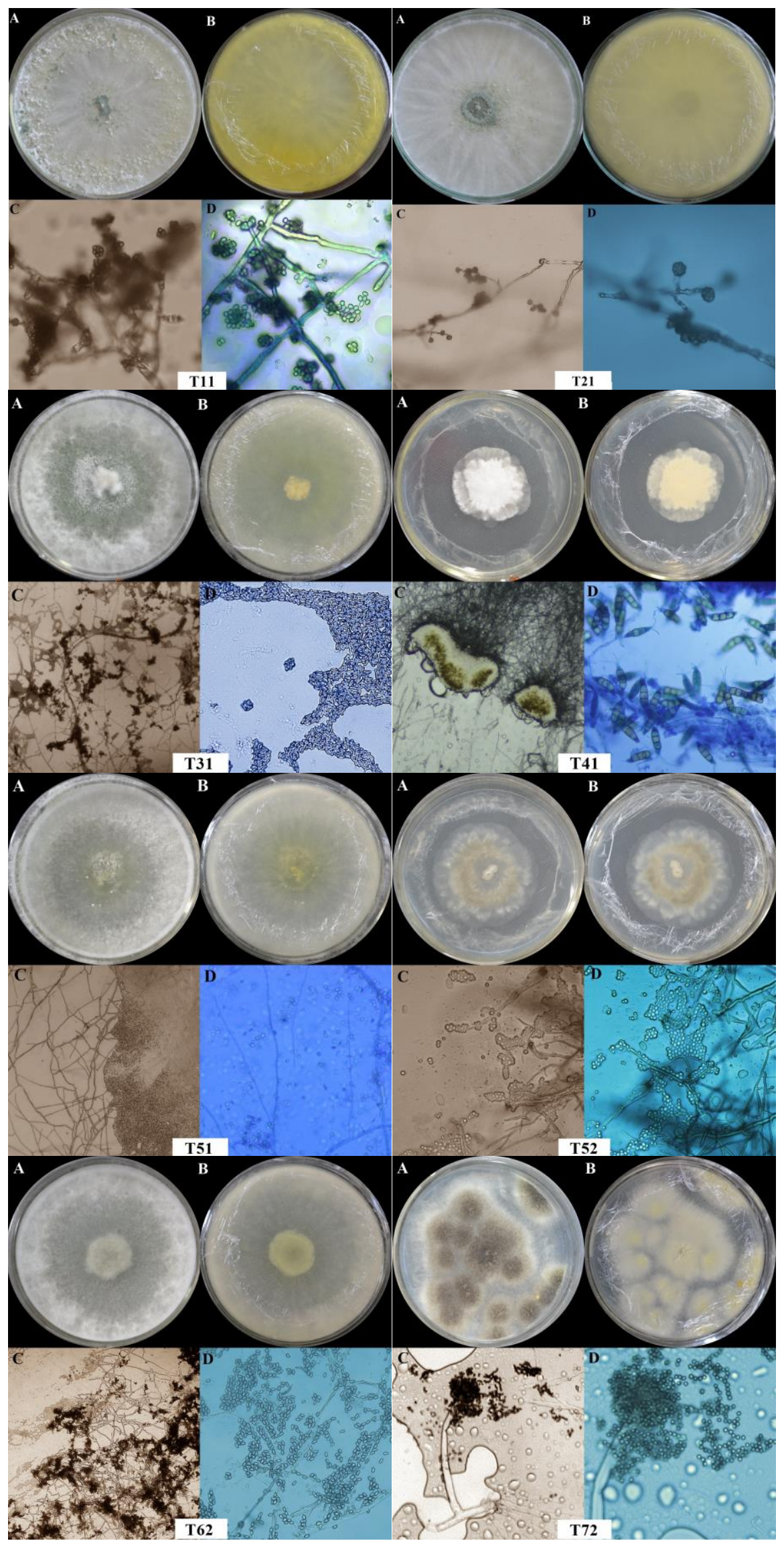

Figure 3. Morphology of endophytic fungi isolated from Syzygium aqueum stem bark; T11. T. aureoviridae, T21. T. harzianum, T31. Trichoderma sp., T41. Pestalotia sp., T51. Unidentified, T52. Beltrania sp., T62. Trichoderma sp., T72. A. niger; A. Front view of colony; B. Reverse colony; C. Conidia without staining; D. Conidia with lactophenol blue dye 


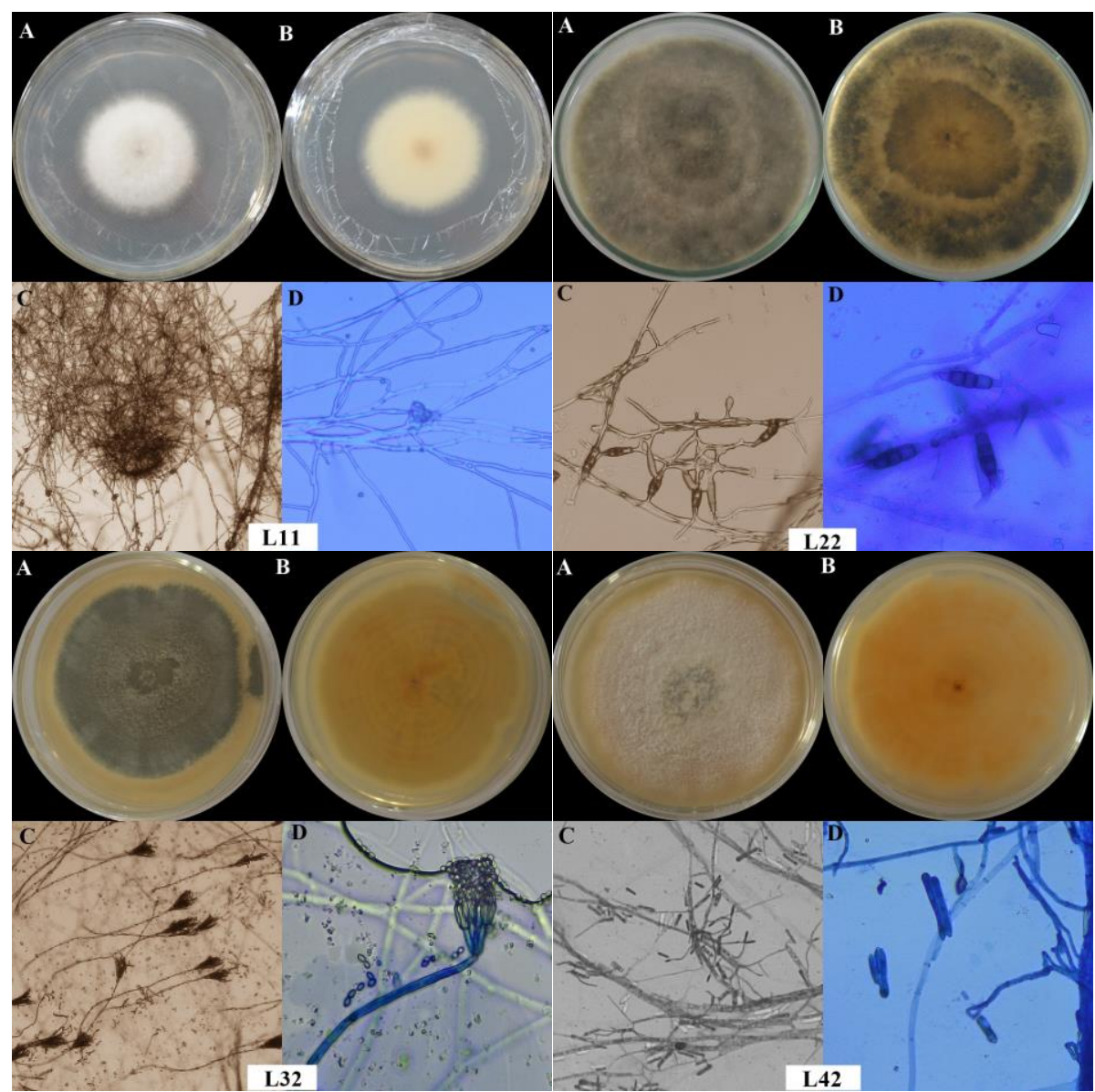

Figure 4. Morphology of endophytic fungi isolated from Syzygium aqueum leaves; L11. Chaetomium sp., L22. Cochliobolus sp., L32. Penicillium sp., L42. Cylindrocladium sp.; A. Front view of colony; B. Reverse colony; C. Conidia without staining; D. Conidia with lactophenol blue dye

Table 3. Fungal diversity and fungal endophytes isolated from different Syzygium aqueum tissues

\begin{tabular}{lcccc}
\hline \multirow{2}{*}{ Taxon (Genera) } & \multicolumn{4}{c}{ Tissues of Syzygium aqueum } \\
\cline { 2 - 5 } & Leaves & $\begin{array}{c}\text { Stem } \\
\text { bark }\end{array}$ & $\begin{array}{c}\text { Root } \\
\text { bark }\end{array}$ & $\begin{array}{c}\text { Total } \\
\text { isolated }\end{array}$ \\
\hline Cylindrocarpon & 0 & 0 & 2 & 2 \\
Aspergillus & 0 & 1 & 2 & 3 \\
Trichoderma & 0 & 4 & 0 & 4 \\
Pestalotia & 0 & 1 & 0 & 1 \\
Unidentified & 0 & 1 & 0 & 1 \\
Beltrania & 0 & 1 & 0 & 1 \\
Chaetomium & 1 & 0 & 0 & 1 \\
Cochliobolus & 1 & 0 & 0 & 1 \\
Penicillium & 1 & 0 & 0 & 1 \\
Cylindrocladium & 1 & 0 & 0 & 1 \\
No. of total fungal isolates & 4 & 8 & 4 & 16 \\
Simpson's index (D) & 0.250 & 0.313 & 0.500 & 0.141 \\
Simpson's index of & & & & \\
diversity (1-D) & 0.750 & 0.688 & 0.500 & 0.859 \\
Shannon index of & & & & \\
diversity (H') & 1.386 & 1.386 & 0.693 & 2.133 \\
\hline
\end{tabular}

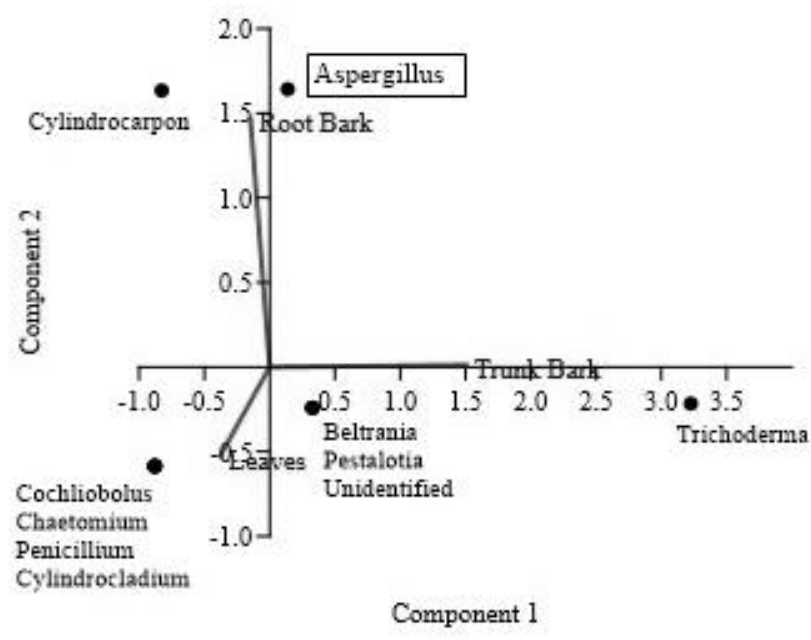

Figure 5. PCA of fungal endophytes isolated from different tissues of Syzygium aqueum. Components 1 and 2 explained 68\% of the total fungal variation 
Table 4. Antimicrobial activity of endophytic fungi

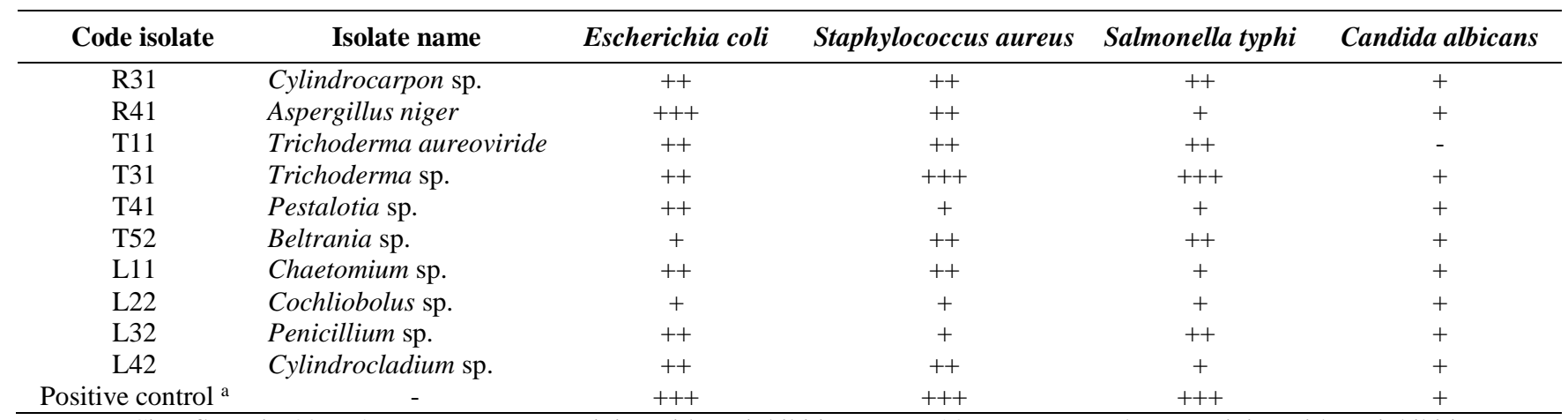

Note: ${ }^{a}$ : Ciprofloxacin $30 \mu \mathrm{g} / \mathrm{mL}$; +++: strong activity with an inhibition zone $>20 \mathrm{~mm}$; ++: moderate activity with an inhibition zone 10-20 mm; +: low activity with an inhibition zone 1-9 mm; -: negative activity with an inhibition zone <1 mm (Islamia et al. 2019).

In conclusion, 16 endophytic fungi were isolated from S. aqueum stem bark, root bark, and leaves. These endophytic fungi belonged to nine genera such as Aspergillus, Cylindrocarpon, Trichoderma, Pestalotia, Beltrania, Chaetomium, Penicillium, Cochliobolus, and Cylindrocarpon. The diversity values of the endophytic fungal populations were $\mathrm{H}^{\prime}=2.133$ according to the Shannon-Weiner index and $1-\mathrm{D}=0.859$ according to the Simpson index. Therefore, it shows that $S$. aqueum can supply a comfortable habitat and nutrients for fungal endophyte survival. Ten endophytic fungal extracts exhibited antimicrobial activity. The high antimicrobial potential was shown to be exclusively by Trichoderma sp. (T31), which acted strongly against $S$. aureus and $S$. typhi but had low antimicrobial activity against $C$. albicans. Therefore, $S$. aqueum is worth further investigating its bioactive secondary metabolites and isolating their bioactive compounds to produce antioxidant and antimicrobial agents.

\section{ACKNOWLEDGEMENTS}

This research was funded by Daftar Isian Pelaksanaan Anggaran (DIPA) of the Public Service Agency at Universitas Sriwijaya, Indonesia 2020. SP DIPA023.17.2.677515/2020, revision IV, July 2, 2020, in accordance with Rector's Decree number 0009/UN9/SK.LP2M.PT/2020, September 28, 2020.

\section{REFERENCES}

Bailey BA, Bae H, Strem MD, Crozier J, Thomas SE, Samuels GJ, Vinyard BT, Holmes KA. 2008. Antibiosis, mycoparasitism, and colonization success for endophytic Trichoderma isolate with biological control potential in Theobroma cacao. Biol Control 46 (1): 24-35.

Barnett HL. 1969. Illustrated Genera of Imperfect Fungi. Burgess Publishing Company, Virginia.

Budiono B, Elfita E, Muharni M, Yohandini H and Widjajanti H. 2019. Antioxidant activity of Syzygiumsa marangense L. and their endophytic fungi. Molekul 14 (1): 48-55. DOI http://dx.doi.org/10.20884/1.jm.2019.14.1.503.
Chua LK, Lim CL, Ling AP, Chye SM, Koh RY. 2019. Anticancer potential of Syzygium species: a review. Plant Foods Human Nutr 74 (1): 18-27.

Cock IE, Cheesman M. 2018. Plants of the genus Syzygium (Myrtaceae): A review on ethnobotany, medicinal properties and phytochemistry. In: Goyal MR, Ayeleso AO (eds) Bioactive Compounds of Medicinal Plants: Properties and Potential for Human Health. Apple Academic Press, Inc., Palm Bay, FL.

Daglia M. 2012. Polyphenols as antimicrobial agents. Curr Opin Biotechnol 23 (2): 174-181.

dos Santos Ferreira da Silva J, López Malo D, Anceski Bataglion G, Nogueira Eberlin M, Machado Ronconi C, Alves Júnior S, de Sá GF. 2015. Adsorption in a fixed-bed column and stability of the antibiotic oxytetracycline supported on $\mathrm{Zn}$ (II)-[2-methylimidazolate] frameworks in aqueous media. PLoS One 10 (6): e0128436. DOI: https://doi.org/10.1371/journal.pone.0128436.

Elfita E, Mardiyanto M, Fitrya F, Larasati J, Julinar J, Widjajanti H, and Muharni M. 2019. Antibacterial activity of Cordyline fruticosa leaf extracts and its endophytic fungi extracts. Biodiversitas 20 (12): 3804-3812.

Elfita E, Munawar M, Muharni M, Suprayetno S. 2013. New pyran of an endophytic fungus Fusarium sp. isolated from the leaves of brotowali (Tinospora crispa). Indo J Chem 13 (3): 209-215.

Gandjar I, Rifai MA. 1999. Pengenalan kapang tropik umum. Yayasan Obor Indonesia. [Indonesian]

Gazis R, Chaverri P. 2010. Diversity of fungal endophytes in leaves and stems of wild rubber trees (Hevea brasiliensis) in Peru. Fungal Ecol 3 (3): $240-254$.

Gustianingtyas M, Herlinda S, Suwandi, Suparman, Hamidson H, Hasbi, Setiawan A, Verawaty M, Elfita, Arsi. 2020. Toxicity of entomopathogenic fungal culture filtrate of lowland and highland soil of South Sumatra (Indonesia) against Spodoptera litura larvae. Biodiversitas 21: 1839-1849.

Hammer, Harper DAT, Ryan PD. 2001. PAST: Paleontological statistics software package for education and data analysis. Paleontol Electron 4: 4-9.

Hariyati T, Soelistya D, Jekti DSD, Andayani Y. 2015. Pengaruh ekstrak etanol daun jambu air (Syzygium aqueum) terhadap bakteri isolat klinis. Journal Penelitian Pendidikan IPA 1 (2): 31-38. [Indonesian]

Jumpathong J, Abdalla MA, Lumyong S, Laatsch H. 2010. Stempholgalactoside, a new stemphol derivative isolated from the tropical endophytic fungus Gaeumannomy cesamomi. Nat Prod Commun 5 (4): 1934578X1000500415.

Kumar DSS, Hyde KD. 2004. Biodiversity and tissue-recurrence of endophytic fungi in Tripterygium wilfordii. Fungal Divers 17: 69-90.

Madhavi M, Ram MR. 2015. Phytochemical screening and evaluation of biological activity of root extracts of Syzygium samarangense. Int J Res Pharm Chem 5 (4): 753-763.

Mapatac LC, Mamaoag NR. 2014. Efficacy of three varieties of Syzygium aqueum (Tambis) as antimicrobial agent and its bioactive component. Int J Sci Clin Lab 9: 1. 
Marinova D, Ribarova F, Atanassova M. 2005. Total phenolics and total flavonoids in Bulgarian fruits and vegetables. J Univ Chem Technol Metallurgy 40 (3): 255-260.

Muharni M, Fitrya F, Ruliza MO, Susanti DA, Elfita E. 2014. Di- (2ethylhexyl) phthalate and pyranone derivated from endophytic fung Penicillium sp. the leave of Kunyit Putih (Curcuma zedoaria). Indon J Chem 14 (3): 290-296.

Nicoletti R, Fiorentino A. 2015. Plant bioactive metabolites and drugs produced by endophytic fungi of Spermatophyta. Agriculture 5 (4): 918-970.

Palanisamy UD, Ling LT, Manaharan T, Appleton D. 2011. Rapid isolation of geraniin from Nephelium lappaceum rind waste and its anti-hyperglycemic activity. Food Chem 127: 21-27.

Palanisamy U D, Ling L T, Manaharan T, Sivapalan V, Subramaniam T, Helme M H and Masilamani T. 2011. Standardized extract of Syzygium aqueum: a safe cosmetic ingredient. Int J Cosmet Sci 33 (3): 269-275.

Photita W, Lumyong S, Lumyong P, Hyde KD. 2001. Endophytic fungi of wild banana (Musa acuminata) at Doi Suthep Pui National Park, Thailand. Mycol Resour 105: 1508-1513.

Pitt JI, Hocking AD. 2009. Fungi and food spoilage (Vol. 519, p. 388) Springer, New York.

Potshangbam M, Devi SI, Sahoo D, Strobel GA. 2017. Functional characterization of endophytic fungal community associated with Oryza sativa L. and Zea mays L. Front Microbiol 8: 325.

Porras-Alfaro A, Bayman P. 2011. Hidden fungi, emergent properties: endophytes and microbiomes. Annu Rev Phytopathol 49: 291-315.

Rahayu ES, Widiatningrum T, Herlina L, Hermayani N, Amalia AR. 2019. The optimal sterilizing compound and culture medium in Elaeocarpus grandiflorus L. in vitro shoot induction. J Phys: Conf Ser 1321 (3): 032040).

Rivera-Orduñ FN, Suarez-Sanchez RA, Flores-Bustamante ZR, GracidaRodriguez JN, Flores-Cotera LB. 2011. Diversity of endophytic fungi of Taxus globosa (Mexican yew). Fungal Divers 47 (1): 65-74.
Rodrigues KF.1994. The foliar fungal endophytes of the Amazonian palm Euterpe oleracea. Mycologia 86: 376-385

Sadeghi F, Samsampour D, Seyahooei MA, Bagheri A, Soltani J. 2019. Diversity and spatiotemporal distribution of fungal endophytes associated with Citrus reticulata cv. Siyahoo. Curr Microbiol 76 (3): 279-289.

Singh R, Shushni MA. Belkheir A. 2015. Antibacterial and antioxidant activities of Mentha piperita L. Arabian J Chem 8 (3): 322-328.

Sobeh M, Braun, MS, Krstin S, Youssef FS, Ashour ML, Wink M. 2016. Chemical profiling of the essential oils of Syzygium aqueum, Syzygium samarangense, and Eugenia uniflora and their discrimination using chemometric analysis. Chem Biodivers 13 (11): 1537-1550.

Sridhar KR, Raviraja NS. 1995. Endophytes-a crucial issue. Curr Sci 69: 570-571.

Strobel G, Daisy B. 2003. Bioprospecting for microbial endophytes and their natural products. Microbiol Mol Biol Revi 67 (4): 491-502.

Talukdar R, Wary S, Mili C, Roy S, Tayung K. 2020. Antimicrobial secondary metabolites obtained from endophytic fungi inhabiting healthy leaf tissues of Houttuynia cordata Thunb., an ethnomedicinal plant of Northeast India. J Appl Pharmaceutical Sci 10 (09): 099-106.

Tehrani M, Sharif Hossain ABM, Nasrulhaq-Boyce A. 2011. Post-harvest physicochemical and mechanical changes in'Jambu Air (Syzygium aqueum Alston) fruits. Aust J Crop Sci 5 (1): 32.

Wang Y, Guo LD, Hyde KD. 2005. Taxonomic placement of sterile morphotypes of endophytic fungi from Pinus tabulaeformis (Pinaceae) in northeast China based on rDNA sequences. Fungal Divers 20: 235-260.

Watanabe T. 2002. Pictorial Atlas of Soil and Seed Fungi: Morphologies of Cultured Fungi and Key to Species $2^{\text {nd }}$ ed. CRC Press LLC, Florida. 